\title{
Saint-Père (Yonne), l'église Saint-Pierre
}

\section{Christian Sapin}

\section{(2) OpenEdition}

\section{Journals}

\section{Édition électronique}

URL : https://journals.openedition.org/cem/3042

DOI : $10.4000 /$ cem.3042

ISSN : 1954-3093

\section{Éditeur}

Centre d'études médiévales Saint-Germain d'Auxerre

\section{Édition imprimée}

Date de publication : 15 août 2003

ISSN : 1623-5770

\section{Référence électronique}

Christian Sapin, «Saint-Père (Yonne), l'église Saint-Pierre », Bulletin du centre d'études médiévales d'Auxerre | BUCEMA [En ligne], 7 | 2003, mis en ligne le 19 octobre 2007, consulté le 22 septembre 2022. URL : http://journals.openedition.org/cem/3042 ; DOI : https://doi.org/10.4000/cem.3042

Ce document a été généré automatiquement le 22 septembre 2022.

\section{(c) (i) (2)(2)}

Creative Commons - Attribution - Pas d'Utilisation Commerciale - Partage dans les Mêmes Conditions 4.0 International - CC BY-NC-SA 4.0

https://creativecommons.org/licenses/by-nc-sa/4.0/ 


\title{
Saint-Père (Yonne), l'église Saint- Pierre
}

\author{
Christian Sapin
}

Commencée en 2001 avec un stage de relevés d'archéologie du bâti (plan et une partie des élévations ${ }^{1}$ ), l'étude du site de Saint-Père s'est poursuivie en 2002 avec un travail sur les maçonneries. Rappelons que le site de l'ancienne église Saint-Pierre à Saint-Père passe depuis longtemps comme pouvant correspondre à la première fondation du monastère de Vézelay (vers 860) avant que ce dernier soit établi sur la colline actuelle à la fin du $\mathrm{IX}^{\mathrm{e}}$ siècle. En préalable à toute fouille du site, la réalisation d'un plan précis des vestiges et une étude du bâti ont établi certaines constatations intéressantes pour l'histoire de l'édifice. À partir des maçonneries subsistantes, on a pu aisément montrer qu'il existait un premier état, antérieur à la réalisation d'un bas-côté au nord au XII siècle, que ce premier état était constitué d'une nef unique longue de 24,50 $\mathrm{m}$ et large de 7,50 m, d'un chœur formé d'une abside empâtée dans un chevet plat et précédée d'une courte travée droite, et à l'ouest d'un petit massif occidental voûté avec un étage. Outre ces particularités qui indiquent une construction peu commune, l'utilisation en différents endroits, en particulier dans le chœur, d'un petit appareil soigné, aux pierres de chaînes d'angles bien taillées (typiques du XI ${ }^{\mathrm{e}}$ siècle), nous invite à voir désormais au moins un état roman qui a pu réutiliser des structures antérieures sans qu'on puisse se prononcer encore sur l'existence in situ d'une première abbatiale. En revanche, la présence en réemploi de fragments de cuves de sarcophages mérovingiens de plusieurs types (entre le $\mathrm{VI}^{\mathrm{e}}$ et le VIII ${ }^{\mathrm{e}}$ siècle d'après la typologie auxerroise), nous conduit à nous orienter vers une origine haute $d u$ site, antérieure aux sources textuelles connues. L'opération devrait se poursuivre en 2003 avec une fouille des parties orientales et occidentales. 


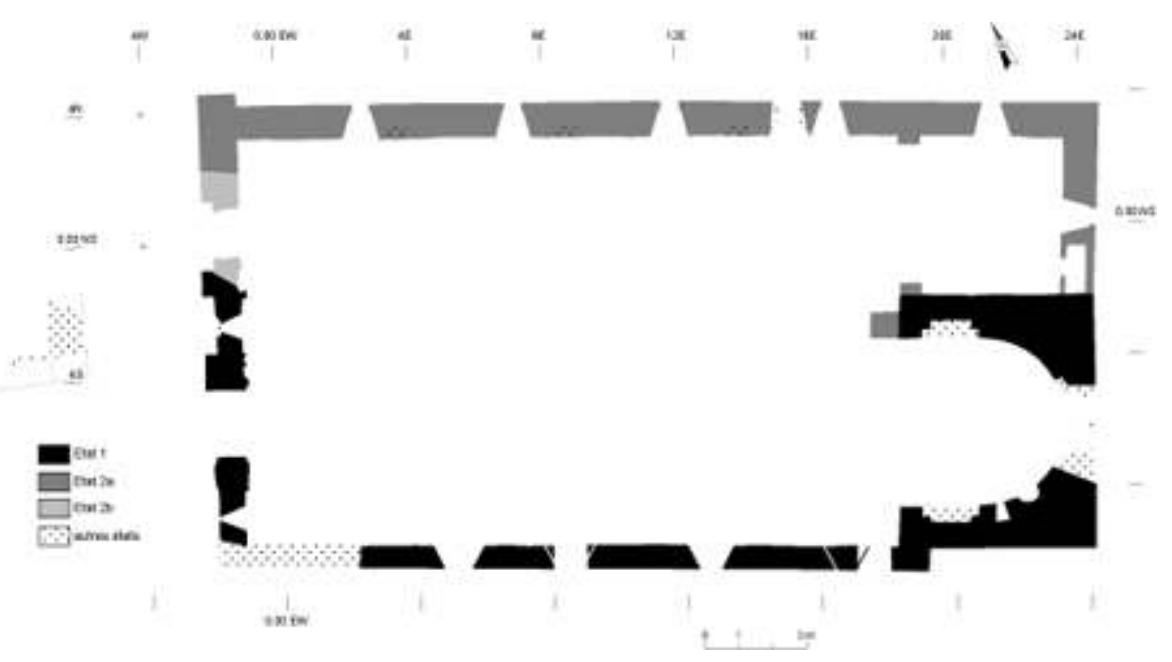

Saint-Père, église Saint-Pierre. Plan de phasage (dessin G. Fèvre - CEM).

\section{NOTES DE FIN}

1. Voir le compte-rendu de stage "L'ancienne église Saint-Pierre à Saint-Père (près de Vézelay, Yonne)", dans Bulletin du Centre d'études médiévales, Études et travaux, 6 (2001-2002), p. 171-172.

\section{INDEX}

Index géographique : France/Saint-Père

Mots-clés : église, Saint-Pierre de Saint-Père 